International Journal of Physical Sciences and Engineering
Available online at www.sciencescholar.us
Vol. 4 No. 1, April 2020, pages: $39-44$
e-ISSN : 2550-6943, p-ISSN : 2550-6951
https://doi.org/10.29332/ijpse.v4n1.424

\title{
Quality Management of Electricity service with Photovoltaic Generation Distributed in Rural Area
}

\author{
(1) corssint \\ Gino Joaquín Mieles ${ }^{a}$, Alcira Magdalena Vélez Quiroz ${ }^{\text {, }}$,iaddy Gina Rodríguez Borgesc ${ }^{c}$ Antonio \\ Vázquez Pérez ${ }^{\text {d }}$
}

Manuscript submitted: 18 February 2020, Manuscript revised: 09 March 2020, Accepted for publication: 27 April 2010

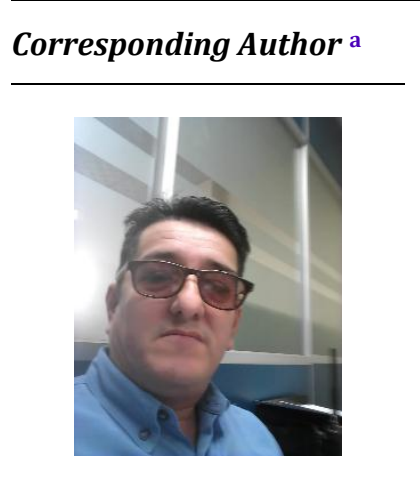

Keywords

distribute generation;

local development;

photovoltaic;

rural electrification;

sustainable;

\begin{abstract}
The need to search for new energy models that are integrally sustainable for the present and the future, especially photovoltaic solar energy that would contribute to a radical change in Manabí Ecuador where populations are living in rural areas away from the electricity grid, which causes impacts negative economic and in some rural electrification projects, and low quality have oriented national policies towards the search for the best alternatives, such as renewable sources, that is, the efficient use of resources and the increase in reliability, coverage, and quality in the electrical supply that Manabí has. Emphasizing "good living" as an objective of the Ecuadorian government, meeting its needs for the development of its agricultural, artisanal, commercial and industrial activities. Thus, avoiding that due to lack or poor quality of energy that prevents them from being able to carry out an activity typical of the countryside or rural areas, these people migrate to the cantonal headwaters, further thickening the cords of misery. The work presents an analysis on the quality of the electric service in isolated areas of the Chone municipality, proposing solutions that can improve the quality of the service, through sustainable energy planning using indigenous resources from the territory.
\end{abstract}

International Journal of Physical Sciences and Engineering (C) 2020. This is an open access article under the CC BY-NC-ND license (https://creativecommons.org/licenses/by-nc-nd/4.0/).

\footnotetext{
Contents

Abstract

1 Introduction...

2 Materials and Methods

${ }^{a}$ Universidad Técnica de Manabí, Portoviejo, Ecuador

b Universidad Técnica de Manabí, Portoviejo, Ecuador

c Universidad Técnica de Manabí, Portoviejo, Ecuador

d Universidad Técnica de Manabí, Portoviejo, Ecuador
}

3 Results and Discussions

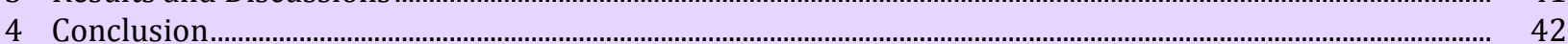

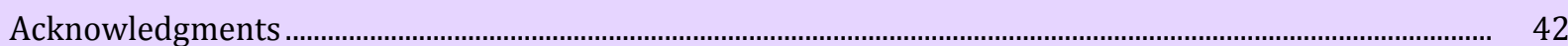




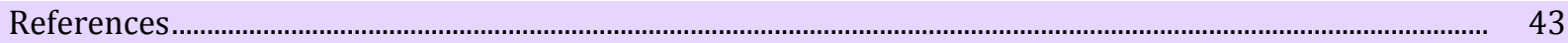

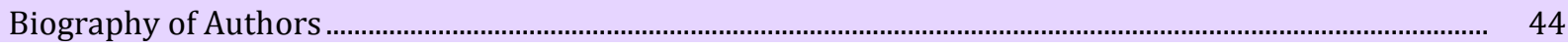

\section{Introduction}

The traditional model makes use of extinct electricity generation sources and the world will continue to depend essentially on fossil fuels, which is one of the causes of greenhouse gas emissions, causing environmental damage, which has induced the use of alternative energy. One of the main resources most used in industrial and commercial activities and that has allowed the development of technologies is electrical energy, which is one of the forms of energy that provides the most advantages and comforts to human beings today.

Service continuity is what has traditionally been called reliability. This quality is an integral and sustainable point, is a very complex task, considering the growing population and therefore the development of technologies, having to use fossil fuels (Marín \& Martín) which massively cover more than $80 \%$ of the world energy demand. The use of fossil energy sources is the cause of $75 \%$ of greenhouse gas emissions. The current rate of oil exploitation contributes to environmental pollution. Over $40 \%$ of global CO2 emissions come from the electricity sector, in Ecuador, it is around 9\% (Hernández, 2012).

At the Latin American level, different actions are carried out to improve the quality of energy in isolated areas using other energy alternatives. For example, Colombia applies studies aimed at the sustainable development of micro-networks following various business models according to social and economic conditions. Another study carried out is related to distribution networks, where even in Ecuador there are deficiencies that affect users, not complying with the quality of the service provided to the population, according to the provisions of the national plan for good live 2013-2017 (SENPLADES, 2009).

The potential of the FRE that Ecuador has and especially the province of Manabí (Rodriguez \& Vazquez, 2018), is adequate to satisfy the existing demands in rural areas, where the technical requirements for generating the current system do not allow offering an adequate quality of the electric service (Gámez et al., 2018), which can be used to satisfy current consumption and offer an ecologically cleaner alternative for the future (Vazquez et al., 2018). Especially photovoltaic energy can be implemented through autonomous systems that work in the form of an island and can be connected to the grid, in support of the centralized system to improve the quality of service, reduce losses (Arauz et al., 2017; Briskman, 1992; Rappaport, 1959; Akbarzadeh \& Wadowski, 1996), also, these types of systems can work in isolation using accumulation systems that will allow them to be useful in risk houses (González et al., 2017). Currently, the photovoltaic market led by China offers competitive prices with any of the generation technologies that have traditionally been used. The advantage from the economic point of view lies in the low operating costs

To carry out the reliability study, we started with the knowledge of the interruptions that are occurring today in the province; but fundamentally the poor quality of the service in rural areas (Rodriguez \& Mendoza, Lack of public lighting and its repercussion on the safety of the inhabitants of the San Felipe sector of the Portoviejo canton, 2018), where for different technical reasons among which are areas rural away from the electricity grid and in other cases with large energy losses and low quality losses and generation deficit, the energy that reaches the users does not have the quality required in relation to the low voltage and frequency of the network interruptions of the service occur frequently, because the electric lines cross wooded areas where the winds and their growth, cause breakage of conductors and fall of the pole and the restoration work of the Service is delayed due to the poor condition of the roads and accesses in winter time, swollen rivers, streams and ravines and in other cases, populations living in rural areas rales far away from the electricity grid with high energy losses and low quality. Where this energy that the distribution company provides is not used in the best way, it does not generate economic profits but rather high losses. 


\section{Materials and Methods}

A bibliographic review was carried out to clearly understand the context of rural electrification and the difficulties that exist in offering quality energy in the rural area of the province of Manabí, being able to learn about the difficulties that exist today in the energy service (Wamukonya \& Davis, 2001; Kamalapur \& Udaykumar, 2011; Saheb-Koussa et al., 2009).

\section{Results and Discussions}

In Ecuador, with the need for a radical change in the electricity sector, it has considered the electrification master plan incorporates sustainable generation based on the use of renewable resources and achieve a relevant social impact through the supply of energy to extending the electricity grid over long distances does not offer solutions, but rather serious effects related to the deterioration of the quality of service. On the other hand, it is undeniable that there are areas not yet served in Ecuador, especially located in the Amazon and the Coast (Garcia, 2014), in which it is not pertinent to arrive with a network extension based on reasons of an economic, technical nature. , environmental impact, and above all respect for the culture of ethnic groups.

The installations of photovoltaic systems, distributed connected to low voltage networks or autonomous in rural areas have not been followed by the necessary education, training, and awareness of the beneficiary population. The lack of empowerment of the population with these solutions and their non-incorporation in the process of identification of needs and installation has greatly limited their sustainability.

Chone is located in the north-central area of the province and is divided into seven parishes located in mountainous areas: 2 urban and 7 rural parishes, it has 52810 inhabitants. At the $69 \mathrm{kV}$ level to go down with power transformers at the $13.8 \mathrm{KV}$ level for medium voltage distribution, and this can be: single-phase $=1 \mathrm{f}$, two-phase $=2 \mathrm{f}$, three-phase $=3 \mathrm{~F}$ down with distribution transformers to reach the consumers in voltages for residential and common subscribers at $240(2 \mathrm{~F}+1 \mathrm{~N}), 120(1 \mathrm{~F}+1 \mathrm{~N})$ in low voltage, around 20 complaints are reported daily, of which 12 are in rural areas of Canton Chone (González \& Villaprado, 2018).

Topographic characteristics are: mountainous area, with abundant rivers and steep mountain-to-mountain elevations, clayey, rocky terrain, on some sides abundant trees and vegetation (Vazquez \& others, Energy, local development and territory planning, 2017). The quality of the electrical service is manifested by continuity and security, from production, supply, and even final consumption. A process that must be planned, organized, and controlled (Rodríguez et al., 2015). The quality of the service is evaluated from a set of indicators shown in figure 1.

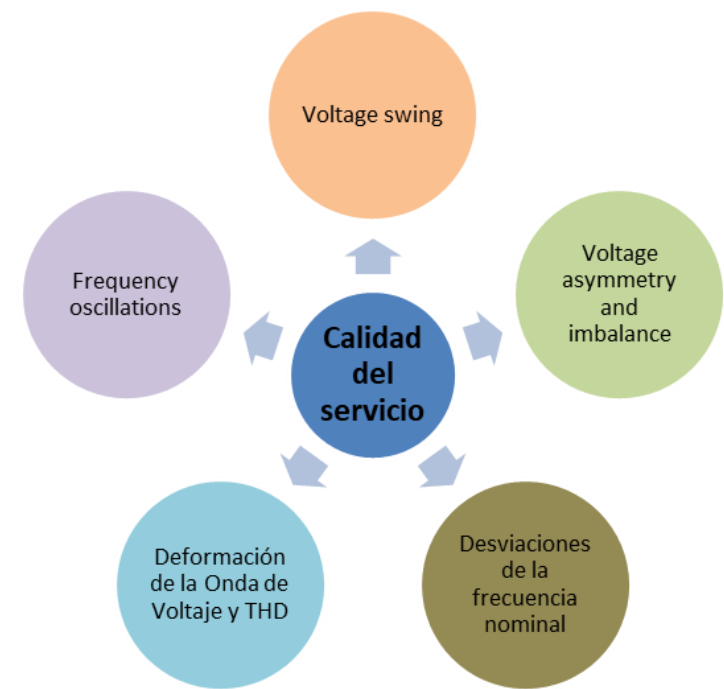

Figure 1. Indicators to measure the quality of service

Mieles, G. J., Quiroz, A. M. V., Borges, C. G. R., \& Pérez, A. V. (2020). Quality management of electricity service with photovoltaic generation distributed in rural area. International Journal of Physical Sciences and Engineering, 4(1), 39-44. https://doi.org/10.29332/ijpse.v4n1.424 
Four parameters are also used as a reference to classify disturbances in the electrical service according to their impact on quality. Frequency variations that rarely occur in systems powered by utility companies, being more common in isolated motor-generator systems in which load variations cause frequency variations.

a) Amplitude variations can occur in different shapes and duration ranges ranging from a very short duration to steady-state conditions.

b) Variations in the voltage or current waveform produced by nonlinear loads, called harmonic distortion, being a steady-state condition.

c) The imbalance between the phases of a polyphase system caused mainly by the operation of loads.

External: Produced by atmospheric discharges (lightning) on power lines, incidental contacts between two power lines mainly.

Internal: they are produced by the operation of disconnection devices, electronic commutation (drive's, PLC's, computers, etc), engine start, among others.

\section{Problems caused by the poor quality of energy}

a) Generation of harmonic currents.

b) Current leaks in the ground network.

c) Voltage variation.

d) Tension fall.

These technical phenomena mainly occur

a) The installation of electronic equipment in a certain environment without having made the necessary modifications to the electrical installation, in such a way that there is no balance between energy consumption and the installation that supports this consumption.

b) The construction of buildings without the knowledge of the electrical charges that will be required

c) Low quality of the electric service of the Canton Chone, Manabí, which causes incapacity for the development of advanced technologies associated with the agricultural sector.

d) Inappropriate increase in the length of a non-projected medium voltage network with its insulation levels and conductor section

e) Increased load without a specific study of its capacity.

f) Extreme weather conditions in rural areas (lightning strikes, heavy rains, humidity).

Establishing a methodology for managing the quality of electrical service in distributed generation systems with photovoltaic plants in rural areas (Niknam, 2003; Borges \& Falcao, 2006; Lopes et al., 2007; BayodRújula, 2009), with an integrative approach, can facilitate the sustainability of the system in Canton Chone, Manabí, Ecuador.

\section{Conclusion}

The particular analysis about the rural communities of the Canton Chone, where the distance to the electrical network could constitute a serious problem to guarantee the quality and continuity of the electrical service through the extension of the network, in addition to the high cost of the projects. of this nature, as well as the results of the evaluation of the solar potential in the province of Manabí and especially in the study area, demonstrate the feasibility for the introduction of photovoltaic technology in any of its applications. Say autonomous systems for the electrification of isolated houses; water pumping systems; articulation of micronetworks in rural communities and; network-connected systems to support increased service quality and reduced centralized system losses.

Acknowledgments

We are grateful to two anonymous reviewers for their valuable comments on the earlier version of this paper. 


\section{References}

Akbarzadeh, A., \& Wadowski, T. (1996). Heat pipe-based cooling systems for photovoltaic cells under concentrated solar radiation. Applied thermal engineering, 16(1), 81-87. https://doi.org/10.1016/13594311(95)00012-3

Arauz, W. M. S., Gámez, M. R., Pérez, A. V., Castillo, G. A. L., \& Alava, L. A. C. (2017). The future of micro-grids in Ecuador. International journal of physical sciences and engineering, 1(3), 1-8. https://doi.org/10.21744/ijpse.v1i3.53

Bayod-Rújula, A. A. (2009). Future development of the electricity systems with distributed generation. Energy, 34(3), 377-383. https://doi.org/10.1016/j.energy.2008.12.008

Borges, C. L., \& Falcao, D. M. (2006). Optimal distributed generation allocation for reliability, losses, and voltage improvement. International Journal of Electrical Power \& Energy Systems, 28(6), 413-420. https://doi.org/10.1016/j.ijepes.2006.02.003

Briskman, R. N. (1992). A study of electrodeposited cuprous oxide photovoltaic cells. Solar Energy Materials and Solar Cells, 27(4), 361-368. https://doi.org/10.1016/0927-0248(92)90097-9

Delgado López, S. E., \& Villaprado Mejía, M. V. (2018). Estudio Del Manejo Postcosecha De La Naranja En El Sitio Daca 1 De La Parroquia Boyacá Del Cantón Chone (Doctoral dissertation).

Gámez, MR, Pérez, AV, Quiroz, AMV, \& Arauz, WMS (2018). Improving the quality of energy with photovoltaic systems in rural areas. Scientific journal , 3 (33), 265-274. https://doi.org/10.14483/23448350.13104

García Serrano, F. (2014). Territorialidad y autonomía, proyectos minero-energéticos y consulta previa: el caso de los pueblos indígenas de la Amazonía ecuatoriana. Anthropologica, 32(32), 71-85.

González, A. E. D., Arauz, W. M. S., Gámez, M. R., \& Alava, L. A. C. (2017). Photovoltaic energy to face an earthquake. International journal of physical sciences and engineering, 1(3), 19-30. https://doi.org/10.21744/ijpse.v1i3.61

Hernández Mora, JA (2012). Methodology for the technical analysis of the massification of photovoltaic systems as an option for distributed generation in low-voltage networks. Electrical Engineering.

Kamalapur, G. D., \& Udaykumar, R. Y. (2011). Rural electrification in India and feasibility of photovoltaic solar home systems. International Journal of Electrical Power \& Energy Systems, 33(3), 594-599. https://doi.org/10.1016/j.ijepes.2010.12.014

Lopes, J. P., Hatziargyriou, N., Mutale, J., Djapic, P., \& Jenkins, N. (2007). Integrating distributed generation into electric power systems: A review of drivers, challenges and opportunities. Electric power systems research, 77(9), 1189-1203. https://doi.org/10.1016/j.epsr.2006.08.016

Niknam, T., Ranjbar, A. M., \& Shirani, A. R. (2003). Volt/Var control in distribution networks with distributed generation. IFAC Proceedings Volumes, 36(20), 547-552. https://doi.org/10.1016/S1474-6670(17)345263

Rappaport, P. (1959). The photovoltaic effect and its utilization. Solar Energy, 3(4), 8-18. https://doi.org/10.1016/0038-092X(59)90002-7

Rodríguez Borges, CG, Sarmiento Sera, A., \& Rodríguez Gámez, M. (2015). Model for the comprehensive assessment of rural electrification technologies. Energy Engineering, 36 (2), 136-145.

Rodríguez, M., \& Mendoza, H. (2018). Falta de alumbrado público y su repercusión en la seguridad de los habitantes del sector San Felipe del cantón Portoviejo. REVISTA RIEMAT, 3(1), 30-34.

Rodríguez, M., \& Vazquez, A. (2018). La energía fotovoltaica en la provincia de Manabí. Portoviejo: UTM.

Saheb-Koussa, D., Haddadi, M., \& Belhamel, M. (2009). Economic and technical study of a hybrid system (wind-photovoltaic-diesel) for rural electrification in Algeria. Applied Energy, 86(7-8), 1024-1030. https://doi.org/10.1016/j.apenergy.2008.10.015

Senplades, S. N. (2009). Plan nacional para el Buen Vivir 2009-2013. Quito: SENPLADES, 14.

Vázquez, A., Rodríguez, M., Saltos, W., Rodríguez, C., \& Cuenca, L. (2018). Rendimiento energético, económico y ambiental de una Central Fotovoltaica de 3,4 KWp en el modo de la generación distribuida (GD). Espacios, 39(47), 34. Obtenido de Rendimiento energético, económico y ambiental de una Central Fotovoltaica de $3,4 \mathrm{KWp}$ en el modo de la generación distribuida (GD)

Wamukonya, N., \& Davis, M. (2001). Socio-economic impacts of rural electrification in Namibia: comparisons between grid, solar and unelectrified households. Energy for sustainable development, 5(3), 5-13. https://doi.org/10.1016/S0973-0826(08)60272-0

Mieles, G. J., Quiroz, A. M. V., Borges, C. G. R., \& Pérez, A. V. (2020). Quality management of electricity service with photovoltaic generation distributed in rural area. International Journal of Physical Sciences and Engineering, 4(1), 39-44. https://doi.org/10.29332/ijpse.v4n1.424 


\section{Biography of Authors}

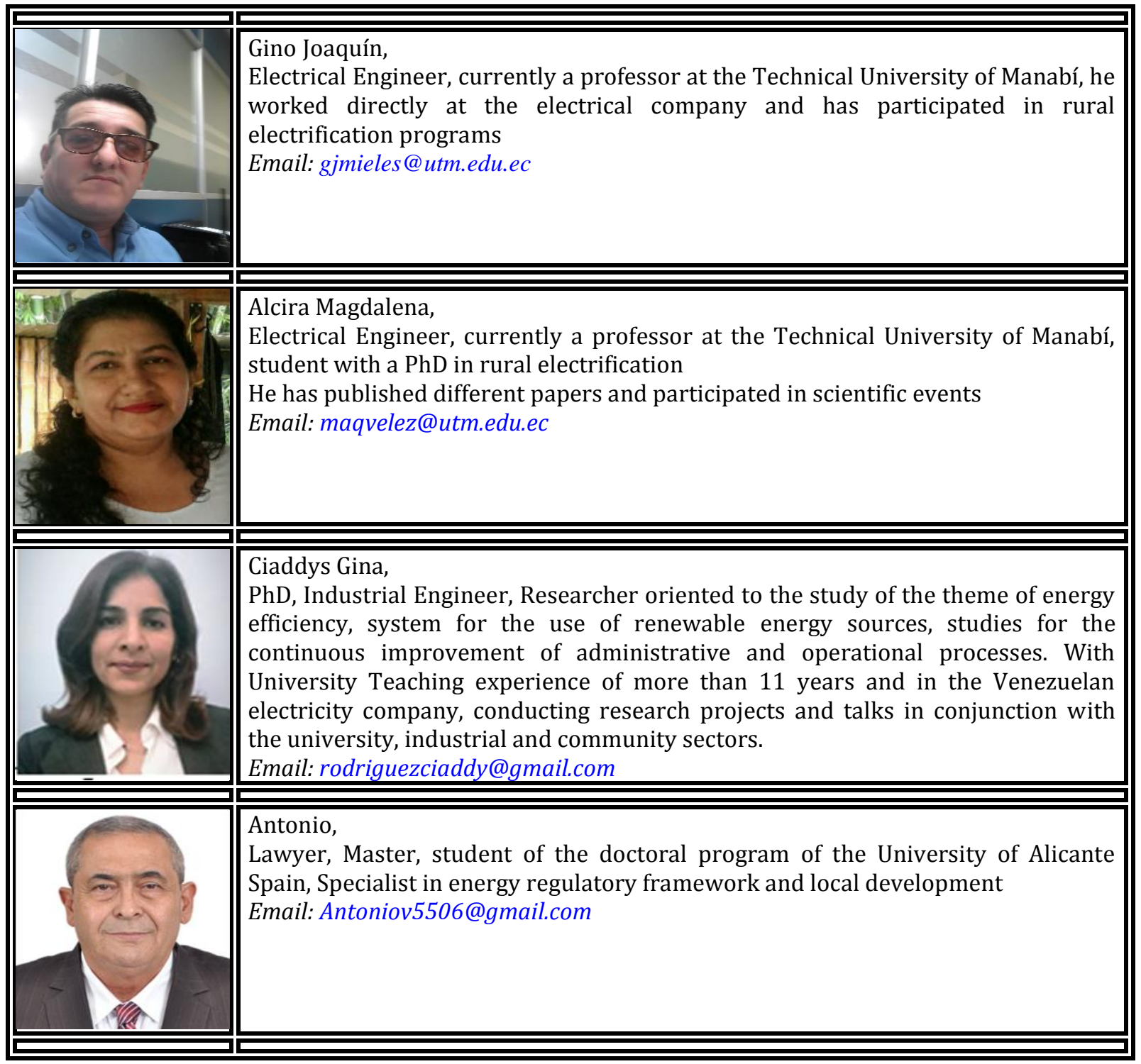

